\title{
INTRODUCTION
}

\section{Rainer Forst: The Justification of Basic Rights}

\author{
Bertjan Wolthuis, Elaine Mak \& Lisette ten Haaf
}

What is the nature of constitutional rights? What is their point? What is the ultimate ground or justification of basic rights? These fundamental and pressing questions and, more specifically, Rainer Forst's answers to them, were the topic of last year's spring meeting (Tilburg, June 10, 2016) of the Vereniging voor Wijsbegeerte van het Recht (The Netherlands Association for Philosophy of Law). This special issue consists of Forst's paper, the responses by Marcus Düwell, Stefan Rummens, Laura Valentini and Glen Newey, and Forst's reply to these responses.

Forst's answer to the questions above is, to summarize, that basic rights need to be viewed as based on, and as specifications of, the fundamental right of free and equal citizens to justification. This right to justification is the central notion in Forst's recent work, including Das Recht auf Rechtfertigung (2007) (The Right to Justification, 2012), Kritik der Rechtfertigungsverhältnisse (2011) (Justification and Critique, 2014) and Normativität und Macht (2015) (Normativity and Power, to be published in 2017). Forst explains that the age-old question of justice - the question: 'Who is entitled to what, and why?,' with suum cuique as its answer formula hides crucial aspects of justice from view. For instance: the issue how the goods to be distributed should be produced or the issue who should decide about the distribution. But the traditional recipient-oriented perspective is not just machtvergessen, it also ignores the fact that justice claims can only be made in discursive practices of justification and criticism.

We should not forget, Forst warns us, that there is a second image of justice, which concerns the equality of opportunity, freedom and power to co-determine the distribution of rights and goods. This basic right to participate in practices of distribution is not itself a good to be distributed but a power to be generated discursively. Inequalities in power have Forst's particular interest: 'Als Opfer der Ungerechtigkeit ist nicht primär die Person anzusehen, der bestimmte Güter fehlen, sondern die, die bei der Herstellung und Verteilung von Gütern nicht "zählt". '1 Justice so understood is opposed to arbitrariness. A legal order becomes arbitrary and turns into a structure of domination if it is based on reasons that cannot be accepted by those subjected to this order. The point is that these subjects have a right to a justification for this order; and that justifications need to

1 Rainer Forst, Kritik der Rechtfertigungsverhältnisse. Perspektiven einer kritischen Theorie der Politik (Berlin: Suhrkamp Verlag, 2011), 33. ('As the victim of injustice is not primarily to be understood the person who lacks certain goods, but the person who does not "count" in the production and distribution of goods.') 
meet the criteria of reciprocity and generality. ${ }^{2}$ The right to justification is in this analysis the single right of rights from which both procedural and substantial norms, both democracy and human rights, can be derived.

This image of justice surfaces in this special issue when Forst explains that it is not only unjust to be deprived of certain basic rights, but that it is also a violation of your rights not to be able to take part in decisions about these rights. A theory of rights needs to take this idea of persons as normative or justificatory authorities seriously and that is why rights are ultimately justified by the right every person has to justification, to be a full member in the process of specifying and justifying basic rights. Therefore, these basic rights are also understood to specify what it means to be recognized as an equal and free normative authority. Social rights, for instance the right to education, are in this theory not seen as means to protect already given interests, as in interest-based theories of rights, but as specifications of what it means to have the equal status of normative authority.

This approach to rights averts the difficulties interest and will theories of rights run into. A problem with the interest theory of rights, Forst argues, is that it needs to indicate which interests are legitimate grounds of rights and which interests are not. But that issue cannot be settled behind the backs of the rightsbearers themselves, who should be allowed to have a say in such practices of specification and justification. So interest theories, properly interpreted, rely on the justification theory. The downside of another rival, the will theory of rights, is that it encompasses only those persons who have the capacity to use their will to a sufficient degree. The justificatory view, on the contrary, is not constructed on the empirical assessment of the capacity of persons to reason or justify, but on the moral (noumenal) view of humans as justificatory beings. ${ }^{3}$

The four commentators highlight different aspects of Forst's theory of rights. Marcus Düwell's comments concern, firstly, Forst's ambition to unite an explicit and strong form of Kantianism with discourse theory. Düwell explains that it is not obvious that the two synthesize. While the Kantian heritage in the Frankfurter Schule, at least in the work of some of its members, is evident, Kant's insights have always been transformed by the Frankfurt School in what is an instance of philosophy's linguistic turn. So while Kant and also Forst, Düwell argues, take as their point of departure the conception of the subject, discourse theory locates justification solely in intersubjective linguistic practices and structures. The argument in discourse theory is that discursive norms or principles are necessarily implied in discourse but not already in the self-understanding of agents. Moral norms, on the other hand, are conceptualized in discourse theory as the outcome of actual deliberations. So Düwell's question is, in short, whether

2 Forst, Kritik der Rechtfertigungsverhältnisse, 40 and Rainer Forst, Das Recht auf Rechtfertigung. Elemente einer konstruktivistischen Theorie der Gerechtigkeit (Frankfurt am Main: Suhrkamp Verlag, 2007) 32-34.

3 See on the person as justificatory being: Forst, Recht auf Rechtfertigung, 19 and ch. 1; Rainer Forst, Normativität und Macht. Zur Analyse sozialer Rechtfertigungsordnungen (Berlin: Suhrkamp Verlag, 2015), ch. 1. 
Forst's theory belongs to the Kantian camp that draws upon the self-understanding of human beings or to the discourse camp. Or is there perhaps a way to unite the two? And if so, how does this unification look like?

Stefan Rummens argues, secondly, that Forst's theory of rights needs to distinguish the philosophical reconstruction and political construction of rights more sharply. This would help explain the distinction between reasons for basic rights: there are reasons based on the status of normative authority and reasons based on reciprocity. Rummens suggests that not only status-based and reciprocitybased reasons for basic rights but also other conceptual pairs in the theory could be better presented as interrelated instances of the primary distinction between the theoretical reconstruction and the practical specification of rights. Moreover, Rummens questions Forst's claim that all basic rights derive from a single source, the right to justification. A closer look suggests, Rummens conjectures, that the right to choose your own ends is the reverse side of the right to justification, which means that basic rights derive from two sources, public and private autonomy, as two sides of a coin.

Finally, Laura Valentini and Glen Newey read Forst's theory of rights as an explanation of rights, as a theory that explains that rights exist (to right sceptics, in Newey's view) or which rights exist (in Valentini's comments). According to Valentini, a successful theory of rights identifies the rights that are usually considered to be rights, and also explains why these rights need to be rights. The difficulty with Forst's theory, she argues, is that it presupposes the very rights it is meant to justify. To ensure that actual processes of justification lead to the correct outcome (a set of basic rights), these processes already need to meet requirements which will resemble, more or less, the rights these processes are meant to generate. Alternatively, if the justification process is viewed as hypothetical, the theory may turn out to be an interest theory in disguise, because specific interests need to be ascribed to the hypothetical parties in order to motivate them to select the correct set of basic rights. Valentini also objects to the indirectness of the theory and the concept of human nature on which the theory appears to rest.

Glen Newey argues that justification may not succeed in explaining rights. It is not a condition of justifying something that those addressed by the person justifying something have a right to such a justification. Hence, Newey cannot see how Forst may succeed in convincing sceptics about rights (who are not sceptics about justification) that the right to justification can be deduced from justification itself. Newey also questions the explanatory power of the right to justification. Does it make sense, he asks, to say that something is wrong because the right to justification is violated? It is more compelling, according to Newey, to say that something is wrong and that this shows up in the fact that it cannot be justified.

Forst's paper and the constructive and critical comments by Düwell, Rummens, Valentini, and Newey, provide the readers of this journal, we hope, with nutri- 
Bertjan Wolthuis, Elaine Mak \& Lisette ten Haaf

tious and balanced food for thought about basic rights and their justification, a topic as relevant as ever. 